\title{
Overview of Urban Mobility in Smart Cities
}

\author{
Overview da Mobilidade Urbana em Cidades Inteligentes \\ Overview de la Movilidad Urbana en Ciudades Inteligentes
}

Received: 07/02/2021 | Reviewed: 07/11/2021 | Accept: 07/14/2021 | Published: 07/24/2021

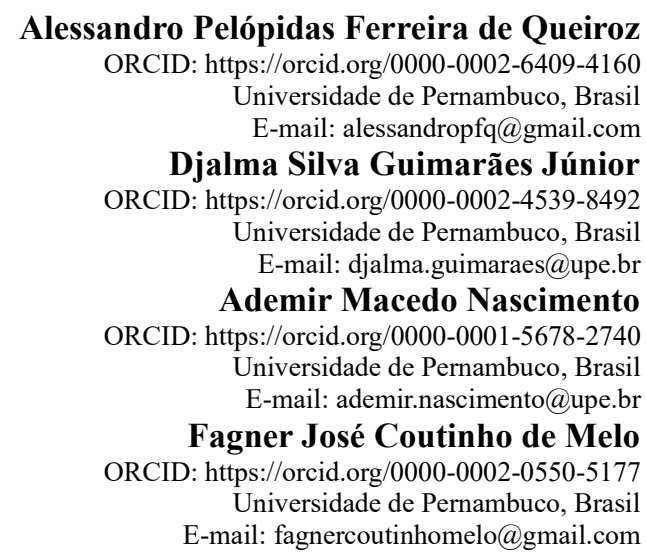

\begin{abstract}
This study aims to obtain information on the most expressive intelligent mobility systems implemented in the main cities of the world, analyze the data and discuss their effects in favor of improving the population's quality of life. This is a narrative literature review study, with a qualitative and exploratory approach. The material collection process was carried out from November 2020 to June 2021, using the Scielo, Scopus, Web of Science, ScienceDirect, Wiley and Proquest (ASIA) databases. The articles analyzed allow us to say that smart mobility is an integrated system composed of several projects and actions aimed at sustainability, governments and private institutions started to develop promising initiatives for the urban mobility segment, through ICT tools in order to solve the problems arising from the impacts of urbanization. In fact, the results of the installation of technological instruments to collect data in cities and the interconnectedness of information enable the creation of intelligent service delivery models with the potential to measure the quality of the thematic axis of mobility, as well as providing opportunities for well-being of citizens and the industrial development of the city.
\end{abstract}

Keywords: Smart city; Urban development; Urban planning; Smart mobility.

\section{Resumo}

O presente estudo pretende levantar os mais expressivos sistemas de mobilidade inteligente implementados nas principais cidades do mundo, analisar os dados e discutir sobre os seus efeitos em prol da melhoria da qualidade de vida da população. Trata-se de um estudo de revisão narrativa de literatura, com abordagem qualitativa e exploratória. O processo de coleta do material foi realizado no período de novembro de 2020 a junho de 2021, com a utilização das bases de dados Scielo, Scopus, Web of Science, ScienceDirect, Wiley e Proquest (ASIA). Os artigos analisados permitem dizer que a mobilidade inteligente é um sistema integrado composto por vários projetos e ações voltadas para a sustentabilidade, governos e instituições privadas passaram a desenvolver iniciativas promissoras para o segmento mobilidade urbana, através de ferramentas de TICs, com a finalidade de solucionar os problemas oriundos dos impactos da urbanização. De fato, os resultados da instalação de instrumentos tecnológicos para coletar dados nas cidades, e a interconectividade das informações possibilitam a criação de modelos inteligentes de prestação de serviços com o potencial de medir a qualidade do eixo temático mobilidade, bem como oportunizar o bem-estar dos cidadãos e o desenvolvimento industrial da cidade.

Palavras-chave: Cidade inteligente; Desenvolvimento urbano; Planejamento urbano; Mobilidade inteligente.

\section{Resumen}

Este estudio pretende relevar los sistemas de movilidad inteligente más expresivos implementados en las principales ciudades del mundo, analizar los datos y discutir sus efectos a favor de la mejora de la calidad de vida de la población. Se trata de un estudio de revisión de literatura narrativa, con enfoque cualitativo y exploratorio. El proceso de recolección de material se llevó a cabo desde noviembre de 2020 hasta junio de 2021, utilizando las bases de datos Scielo, Scopus, Web of Science, ScienceDirect, Wiley y Proquest (ASIA). Los artículos analizados permiten decir que la movilidad inteligente es un sistema integrado compuesto por varios proyectos y acciones orientadas a la 
sustentabilidad, gobiernos e instituciones privadas comenzaron a desarrollar iniciativas prometedoras para el segmento de movilidad urbana, a través de herramientas TIC con el fin de resolver los problemas derivados de los impactos de urbanización. De hecho, los resultados de la instalación de instrumentos tecnológicos para la recolección de datos en las ciudades, y la interconexión de la información permiten la creación de modelos inteligentes de prestación de servicios con potencial para medir la calidad del eje temático de movilidad, además de brindar oportunidades para el bienestar de los ciudadanos y el desarrollo industrial de la ciudad.

Palabras clave: Ciudad inteligente; Desarrollo urbano; Planificación urbana; Movilidad inteligente.

\section{Introduction}

Technology advancement in various sectors of societies encouraged the modernization of cities in order to provide efficiency in the provision of public services and quality of life for the population. Some world authorities have awakened to the need to take care of the planet and started the process of reducing the pollution of their countries, cities and citizens, through the implementation of computerized communication mechanisms associated with environmental sustainability and economic growth.

Since the First Industrial Revolution, the accelerated swelling of urban centers has been observed, as well as the consequences of this rampant urbanization that compromised the infrastructure of cities and the living conditions of their inhabitants, such as chaotic traffic in large cities, lack of public safety, irregular housing occupations, illness of the population due to lack of access to basic sanitation, among others. According to the Summit Mobilidade Urbana (2021), in the ranking of cities with the worst traffic in the world, Brazil appears in 24th position with the city of Recife.

However, the above situations are social matters that can be reversed by Information and Communication Technologies (ICTs), which influenced the Fourth Industrial Revolution or 4.0 Revolution and smart cities (Paseto; Martins Martinez \& Przeybilovicz, 2020). The incorporation of digitalization into the industrial activity, which characterizes Industry 4.0, enabled the integration and control of production, from sensors and equipment connected in a network and the fusion of the real and virtual world (IEDI, 2018), as well as starting to allow the development of new products and/or autonomous services (Sendler, 2013), which were used to diagnose urban problems and propose intelligent solutions of all kinds, in various cities around the world, among them initiatives in the urban mobility segment.

In addition to it, the 2030 Agenda of the United Nations (UN) foresees, among the Sustainable Development Goals (SDGs), goals related to urban mobility, such as number 11.2 which aims to provide reachability of "safe, affordable, accessible, and sustainable transport systems for all, improving road safety, notably by expanding public transport, with special attention to the needs of those in vulnerable situations [...]." (Plataforma Agenda 2030, 2021).

Therefore, the specialized literature presents in a singular way studies corresponding to certain intelligent mobility systems developed in some cities in Asia, or in certain cities in Europe, or even in the main cities of North America and Latin America. However, none of these studies aimed to verify the smart mobility systems developed in cities identified by the rankings as the main smart cities in the world.

Therefore, this study intends to analyze the most expressive intelligent mobility systems implemented in the main cities of the world, in order to disseminate these experiences, as well as examine the data and discuss their effects in favor of improving the quality of life of the population.

Initially, the first section presents the methodological approach adopted to conduct the proposed research. Next step, the approach focuses on exploring the breadth of the Smart City concept, due to its notorious variety. In sequence, the discussion aims to analyze the importance and effectiveness of urban development and urban planning, respectively. Considering the research objective, the third section aims to know the concepts of smart mobility. The last section will bring together the main smart cities in the Asian, European and American continents to present the smart mobility systems implemented there. 


\section{Methodology}

This paper is a narrative literature review study, with a qualitative and exploratory approach. According to Rother (2007, p. v): "narrative review articles are broad publications appropriate to describe and discuss the development or 'state of the art' of a given subject, from a theoretical or conceptual point of view". These are texts that constitute the analysis of scientific literature in the author's interpretation and critical analysis.

Despite the fact that its strength of scientific evidence is considered low due to the impossibility of reproducing its methodology, narrative reviews can contribute to the debate of certain themes, raising questions and collaborating in the acquisition and updating of knowledge in a short period of time.

The material collection process was carried out from November 2020 to June 2021, however, a time filter was not adopted. Electronic databases were searched, such as: Scielo, Scopus, Web of Science, ScienceDirect, Wiley, and Proquest (ASIA). The descriptors used were smart cities, urban development and urban planning, smart mobility, mobility and Singapore, mobility and London, mobility and Barcelona, mobility and New York, mobility and Montreal, mobility and São Paulo and mobility and Brasília. The selected field to be searched was "subject" or "word", when the subject option was non-existent. The Boolean Operator "and" was used, not using truncations. The inclusion criteria were articles with full availability: which presented cohesion with the theme smart cities and smart mobility; and with research on mobility systems in the cities of Singapore, London, Barcelona, New York, Montreal, São Paulo and Brasília.

Figure 1. Diagram representing the procedures for selecting the articles.

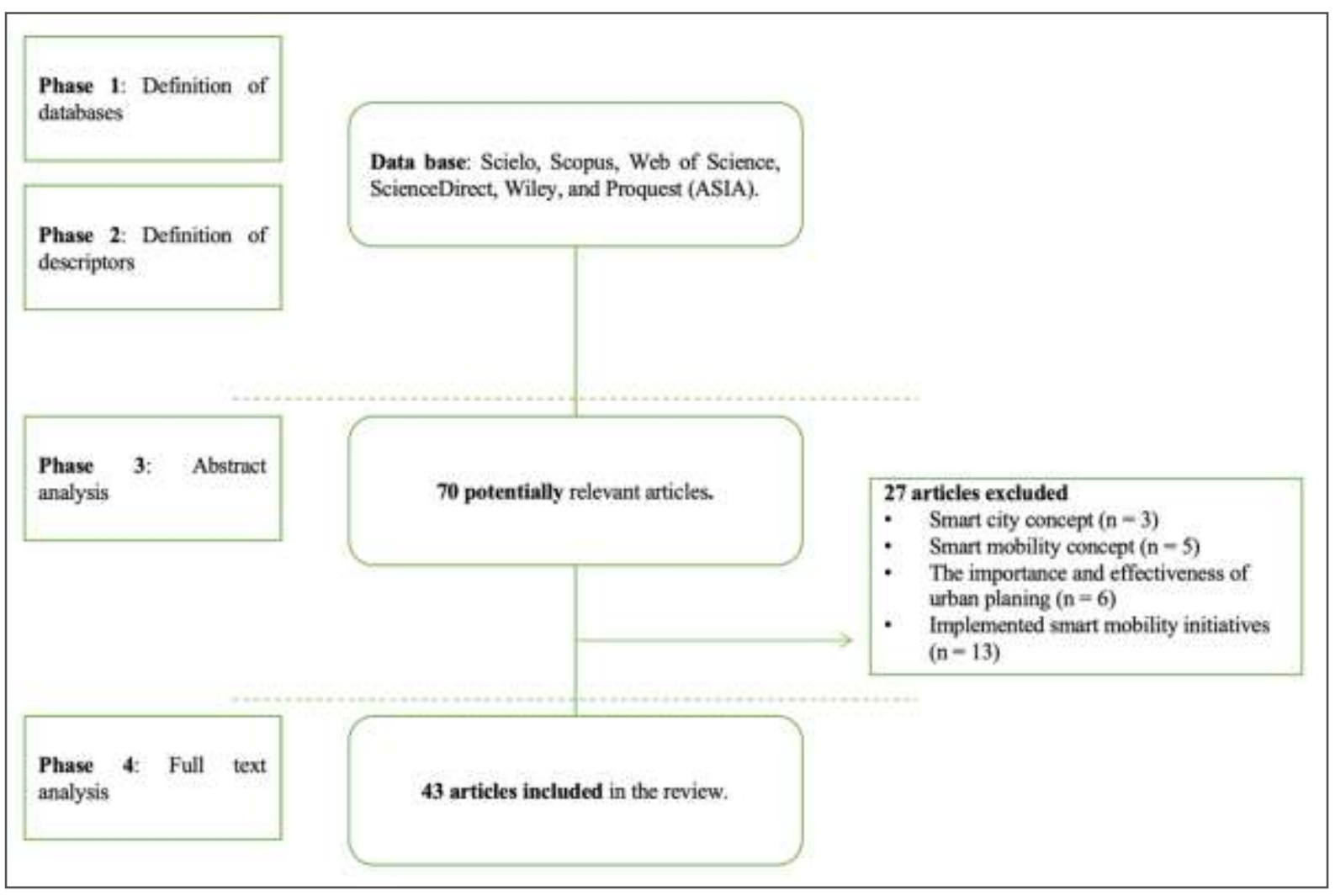

Source: Authors.

From the articles found, were removed those that: (a) did not address the concept(s) of smart city (n=3); (b) did not address the concept(s) of smart mobility $(n=5)$; (c) did not discuss the importance and effectiveness of urban planning $(n=6)$; $(d)$ did not present effectively implemented initiatives of smart mobility system(s) (n=13). 
Therefore, 43 articles were selected to be critically analyzed and included in the review. The database was being supplemented with books, websites, dissertations, and theses published and available in university databases, particularly regarding information on cities and smart mobility systems in Brazil, due to the scarcity of research published in indexed journals. Finally, these materials were read in fully, categorized and critically analyzed. The results and discussions on the subject in question will be presented below.

\section{The Amplitude of the Smart City Concept}

Cities, especially the oldest ones, arouse fascination, sharpen curiosities, and provoke in human beings the urge to elucidate their mysteries. This is because cities are at the origin of what was established by humanity as the signs of the flourishing of the (first) civilizations: agriculture, the wheel, writing, the first urban settlements (Pesavento, 2007).

Although the appreciation of the past of cities is a relatively recent common characteristic of societies, as pointed out by Abreu (1998), the importance of this dimension for the singularity of cities is not denied. Therefore, the search for the identity of places occurs through the materialization of the landscape, the preservation of "institutions of memory" (museums, archives, libraries, etc.), as well as the presence of the past in the culture and daily life of these places.

This concern with the memory of cities (an essential element of a place's identity) is justified by the importance of ancient cities, which over time played a fundamental role in economic development and growth, supporting the exchange of ideas and opportunities of collaboration (Fernández; Collado \& Guzmán, 2015). According to Pesavento:

At this dawn of time, millennia years ago, they were there, marking a path, in square or circular shape; defining an organized and built space, soon made iconic of the urban — towers, walls, public buildings, squares, markets, temples; to exhibit complex and unusual sociabilities in the population agglomeration they housed; to show the presence of a regulating power of life and another ordering power beyond, in the transcendence of the divine (Pesavento, 2007, p. 11).

However, due to cities or at least some of them, several conflicts have taken place in a not-so-distant past, they were the stage of terrible wars and even today, in some parts of the planet territorial disputes occur. The city of Jerusalem might be the most important of all to present the issue. Although, this study will focus on conflicts arising from contemporary times, those that negatively affect urban areas producing inconveniences such as traffic jams and pollution that causes economic, social and environmental impact (Fernández; Collado \& Guzmán, 2015).

Given the current complexity and dynamics of cities, which at the same time present themselves as places of economic growth and wealth creation, are also recognized for promoting poverty, social inequality and environmental degradation (Musakwa \& Niekerk, 2015). Challenges that require a paradigm shift, which can be made possible by the adequate planning of cities that suffer from such problems.

In this scenery, considering that the urban population exceeds $68 \%$ of the world population (United Nations, 2018) and that cities need water, raw materials and processes to generate energy, supplying the indispensable resources for their inhabitants and as a consequence they release the waste (Kennedy; Cuddihy \& Engel-Yan, 2007). The most important challenge to be implemented by cities today would be sustainable urban development is what Flores (2010) argues.

The aforementioned concern with sustainability encouraged the birth and international dissemination of the concept of sustainable city in the late 1980s, as explained by Elias and Krogstie (2017). Sustainable development came to be defined as the one which meets the needs of the present without compromising the ability of future generations to meet their own needs (Brundtland, 1987, p. 41).

Therefore, sustainable cities are those where the integration of planning and administration of the urban environment takes place with the objective of providing the well-being of citizens and society as a whole, promoting equality and social 
inclusion, as well as being economically productive and having its buildings in harmony with nature, without forgetting to preserve its historical roots and be maintained for all generations (Flores \& Teixeira, 2017, p. 68).

The term smart city, on the other hand, emerged in the 1990s (Albino, 2015), with a different meaning from the one exposed about the sustainable city. According to Albino (2015), the expression was used to emphasize the importance of ICTs applied to the city, so that it could be considered intelligent.

In any case, it is worth noting that the concept of smart city is a new concept that is based on a multidisciplinary approach according to the area of expertise (Chourabi et al., 2012). Which means that it is possible to find in the specialized literature distinct definitions of smart cities. To illustrate the aforementioned variety of concepts, three positions on the smart city are presented below.

Firstly, Chourabi et al. (2012), the authors describe that the city's new intelligence concerns the increasingly effective combination of four highly technological elements: digital communication networks, which they compare with nerves; the collective embodied intelligence identified as the brain; sensors and tags recognized as sensory organs; and software, understood as knowledge and cognitive competence.

Secondly, Pan et al. (2013) define smart city as the way that could alleviate many of today's critical problems related to traffic, environmental pollution and the scarcity of natural resources. The concept in question is similar to the definition of a sustainable city, seen previously, which is why it is so common to confuse the two expressions. However, it is worth clarifying that the scope of the smart city is to use ICTs to face the problems corresponding to the environment, consciousness of creating products and/or services aimed to reduce pollution and global warming, offering solutions to the scarcity of water, electricity and natural resources.

The third concept, Pellicer et al. (2013) argue that the smart city can still be understood as the environment that integrates social actors, whether they are citizens, government, universities or companies, inserting intelligence into the city's infrastructure and services to meet the needs and solve the problems that affect these actors.

It is also important to emphasize that this diversity of concepts is accompanied by other nomenclatures used in the literature as synonyms for smart city. In addition to the term sustainable city, examples are: digital city, conscious city, city of the future, creative city, innovative city. It can be said that all these expressions mentioned here have in common the use of ICTs to solve the problems arising from the impacts of urbanization.

Due to this lack of consensus in the literature regarding the concept of smart city, Harrison et al. (2010) present three essential characteristics that, in their opinion, guide the concept of smart city: instrumented, interconnected and intelligent. The author goes on to describe each of them: the instrumented city gathers all possible data from sensors, video cameras, radio frequency identifiers and the global positioning system; the interconnected city enables the connection between the physical data collection systems and the software systems of the companies that produce the operations of the city's services; and the smart city analyzes, creates models, optimizes and interprets the collected data (Harrison et al. 2010), all of this to offer innovative products and services, as well as an opportunity to improve citizens' well-being and industrial development of the city (Caragliu et al., 2009).

Komminos (2008, p. 1) adds that the construction of the intelligent city depends on the junction of the three forms of intelligence, identified as human, collective and artificial that is, the intelligence "[...] of human beings that constitute the population of cities, the collective intelligence of innovation institutions, and the artificial intelligence of networks and digital applications."

With the implementation of these intelligences, the smart city "should excel in six aspects of urban, economic and living development, which are: the economy, society, government, mobility, the environment and quality of life" (Cury \& Marques, 2017, p. 106), which were established by the Center of Regional Science, through the Ranking of European medium-sized cities 
(2007).

However, for the present study, greater attention will be given to the mobility aspect, considering, as Abdala et al. (2014), that this characteristic permeates several and different areas of knowledge in a multi and interdisciplinarity, which means that for urban development a smart city is essential the effective participation of the knowledge of professionals in math, science, biology, and humanities areas, among others, to solve the problems arising from mobility.

\section{Urban Development and Urban Planning}

Previously, there was a direct and intimate relationship between city and development. At the same time cities are recognized for their development-related progress, understood as economic growth and industrialization, their leading role has attracted people from the countryside to cities. This rural-urban migration process led to disorderly urbanization and all the consequences corresponding to the lack of planning and infrastructure to accommodate this population coming from the countryside. It is worth mentioning: unemployment, crime, slums, traffic jams, air and water pollution.

The urbanization process in Brazil began in the mid-twentieth century, mainly under the influence of the aforementioned rural-urban migration and the explosion of industrialization in large cities. For example, in 1950 the urban population was $36.16 \%$, while the rural population was $63.84 \%$. Fifty years later, the urban population rose to $81.25 \%$ and the rural population to $18.75 \%$ (IBGE, 2010). This migration process significantly affected the natural environment of Brazilian cities, according to Abiko and Moraes (2009, p. 6): "The urban population and its economic activities require resources that far exceed what the city itself can provide. In this way, the city needs food, water and energy from other places. Added to this is the necessity to dispose of the waste produced by it, which cannot be absorbed by the local ecosystem."

At first, industrialization in Brazil triggered migration, accelerated urbanization and capitalist expansion with the promise of economic growth and development. Bresser-Pereira (2014) teaches that economic growth refers to the increase in production, income and expenses that are typical of an economy, that is, it assumes a quantitative characteristic which allows measuring the generation of wealth in a country, and even make comparisons with other countries. An example of which is the Gross Domestic Product (GDP), adopted worldwide as a measure of growth. On the other hand, "economic development is the historical process of capital accumulation incorporating technical knowledge that increases the population's living standard" (Bresser-Pereira, 2014, p. 53). Therefore, the assessment is made using quantitative and qualitative models.

Following this concept in terms of economic growth, the promise of industrialization and urbanization was fulfilled as more than $80 \%$ of GDP is generated in cities. It turns out that the same cannot be said about economic development, since urban development resulting from the migration process caused several imbalances in cities, among them, it is worth noting that the highest levels of pollution in the world are in cities (Dobbs et al. 2011). As in the theory of Delfim Netto (2008), the "cake" grew, but unlike the outcome intended by the author, the development results were shared in order to increase inequality.

Faced with the negative consequences promoted by the idea of development as economic growth and industrialization, Veiga (2005) presents, as a second alternative, the concept of development as economic growth with social development and improved life quality, a thought quite similar to what came to later be called sustainable development.

Although the commonly accepted definition of sustainable development is the one presented by the Brundtland Report, as mentioned before, it is opportune here to describe the definition attributed by the International Council of Local Environmental Initiatives (ICLEI), according to which sustainable development must be understood as one that "delivers basic environmental, social, and economic services to all, without threatening the viability of the ecological and community systems upon which these services depend" (ICLEI, 1995).

The new sustainable development model has influenced and justified several actions in the urban environment, such as: the Kyoto Protocol, where the signatory countries pledged to reduce gas emissions; the Paris Agreement, with the aim of 
containing the increase in global warming; and encouraging the use of non-motorized transport services, such as bike-sharing system, among others.

In this sense, urban planning should be the appropriate instrument to make these actions feasible. Santos (2006) teaches that, throughout history, it is possible to identify four different approaches in urban planning: hygienist policy instrument; technocratic-modernist; urban planning in view of the emergence of social movements; and urban planning reduced to urban entrepreneurship. Without any intention here of describing in detail each of the aforementioned phases experienced by urban planning, it can be stated succinctly that, until today the instrument in question has never effectively achieved the objectives for which it was designed, to meet the collective interests, to improve the living conditions of citizens, or in words of Carvalho (2001, p. 979) urban planning consists of the "coordination of public decisions and actions in time and space, which taking the urban problem as a privileged field for intervention as a reference would aim to promote the development of cities."

Initially, urban planning was used as "[...] policy instrument to face the social, political and economic transformations resulting from the emergence of the urban-industrial-based society" (Santos, p. 55). As already mentioned, due to the growing urbanization of the population and the significant demographic growth of some cities, such an instrument was justified as a means of enforcing public policies to control urban land use, housing programs and other urban infrastructure.

However, the hygienist approach did not resolve the issue regarding the high demographic occupation of some cities, in fact, it can be said that it contributed to the emergence of other problems of a collective order, such as the cases of sanitation and urban transport, which started to demand the intervention of the State to solve these issues. According to Santos (2006, p. 62), the concept of technical-modernist urban planning was mainly responsible for "[...] physically expanding cities using the available technical means, [...]" especially adapting the city to the use of the automobile, given that it conceived the city as a result of four functions: living, working, circulating and leisure. Even so, the author states that this model was not successful in facing up to accelerated urban growth, especially because it did not address the problem of metropolization of poverty ${ }^{1}$, a consequence of the modernization project of the Brazilian military regime.

In this scenario, the low-income population, who lived in the periphery, became part of social movements demanding public recognition and investments in infrastructure by the State. And the MNRU (Movimento Nacional Pela Reforma Urbana), due to the process of discussion and drafting of the Federal Constitution of 1988, even presented proposals for amendments to the Constitutional Assembly. Although the proposals motivated the introduction of articles 182 and 183 of the Federal Constitution of 1988, Silva (2004, p. 47) explains that the proposals referring to public transport, public services and others, were not fully incorporated by the National Congress, which limited it to the regulation of the local Master Plan. This represented a failure for the MNRU, as reported by Souza:

Popular participation which should be seen as a key factor in boosting the democratization of planning and management was left aside, as can be seen when comparing the very little attention given to urban development councils in comparison with instruments such as "created soil", both in academic discussions and in progressive master plans (Souza, 2002, p. 161).

In this context of activism of urban social movements, there is also a greater commitment of the State, with the creation of mechanisms such as the Statute of Cities (Law N. 10.257 of 2001) and the Master Plan and the Land Use and Occupation Laws. However, the existence of urban legislation by itself does not solve urban problems without investments being done. And the "financial inability of the State to bear the cost of carrying out construction, even those considered necessary in order to

\footnotetext{
1 "The metropolization of poverty corresponds to the transference of poverty from rural areas to the periphery of metropolitan spaces, where there is no urban infrastructure and land is therefore cheap. This absence of public power corresponds to a type of populist urbanism, predominant between 1930 and 1964, which resulted in government leniency with the illegal occupation of urban space, for which the State no longer took responsibility, since it did not recognize the existence of these illegal spaces" (Santos, 2006, p. 63).
} 
enable urban growth, has led to the establishment of partnerships with the local business community" (Santos, 2006, p. 65). However, regarding the assessment of the viability of investments, it is necessary to take into account that the private sector uses criteria different from those of the public power, since in most situations there is no real commitment to urban planning in favor of the collective interest.

As an example of this, there are the so-called Real Estate, Residential and Services Complexes (CIRS)", which in the metropolitan region of Recife, is recognized as Reserva do Paiva. It is worth clarifying that the CIRS should not be confused with closed residential subdivisions and/or other types of condominiums, since according to real estate developers, in general, they are called "planned neighborhoods" or even "planned cities". However, as mentioned previously, the segment by very exclusive criteria, according to Barbosa:

This means that, by assuming the leading role in the planning and governance of the CIRS, private capital goes far beyond just building segmented projects for the high-end market (residential, commercial or services). In fact, it is increasingly acting in what real estate developers call "urban development", that is, it also takes on condominium management and meticulously plans the services and products that will be offered in these spaces, in an attempt to establish a relative self-sufficiency in relation to the rest of the city (Barbosa, 2016, p. 787-788).

It is clearly observed that the proposed solution made possible by CIRS is totally disconnected from the real urban issues that involve the rest of the city. In fact, the complex represents a bubble, capable of imposing a distance between the "solution" and urban problems. The "solution" is intended for a small portion of the population, who can afford to escape urban problems most of the time given the self-sufficiency character of the proposal. But the urban development implemented there does not impact the urban problems that affect the popular masses.

Thus, considering the complexity and evidence of the ineffectiveness of articulations between private capital and public authorities in the urban planning process, it is concluded that it is important to promote public policies for urban development and planning based on the concepts of sustainable and smart cities to solve the countless difficulties related to the aggravation of real or potential urban problems. After all, the creation of directives concerned with the quality of life of citizens, added to the use of technologies, are able to facilitate the alignment of interests in the urban planning process and other strategic plans (Kobayashi, et al., 2017).

In this regard, considering the binomial mobility and urban planning, the main aspect of the study in question, the use of technologies is essential to ensure effective planning due to the need to carry out the analysis of several factors: "the relationships between the population's places of residence and work; land use and occupation rules; transport modalities; and the road infrastructure conditions".

\section{Conceptual Notions of Smart Mobility}

Among the various problems arising from traditional cities, urban mobility is one of the issues that arises in large cities, drawing the attention of the public and private sectors to define urgent and viable solutions. Intense traffic and the inefficiency of the public transport system have long been the main phenomena of urban mobility faced daily by populations around the globe. In this context, ICTs tools have come to be considered essential to transform traditional cities into smart cities (Holzer \& Kim, 2006).

However, Aletà, Alonso and Ruiz (2017) clarify that the concept of smart mobility is not limited to the use of ICT tools to solve only congestion and public transport, in fact, according to the authors the concept is broader and aims to achieve innovative solutions and sustainable ways to offer mobility to people through green public transport, fuels and propulsion systems supported by technology and the proactive behavior of citizens (Neirotti, et al., 2014). 
In this sense, Lopez-Carreiro and Monzon (2018) state that the smart mobility paradigm emerged in the 1990s, and currently, mobility systems identified as smart has taken advantage of technology to improve the general urban network, especially the quality of life of inhabitants, which means to say that smart mobility is interrelated with the social, environmental, ecological and economically sustainable spheres. Therefore, mobility cannot be considered smart if it is not sustainable, the most substantial difference between sustainable mobility and smart mobility is that smart mobility is an integrated system composed of several projects and actions all focused on sustainability (Pinna; Masala; Garau, 2017). Still, it is necessary to highlight the difference between mobility and smart mobility, which according to Manville et al (2014) is directly related to public accessibility and information in real time, since such conditions provide an improvement in the provision of services, saving time, improving the journey, saving money and reducing carbon dioxide $\left(\mathrm{CO}_{2}\right)$ emissions.

Regarding $\mathrm{CO}_{2}$ emissions, Staricco (2013, p. 342) denounces that the transport sector has the greatest impact on energy consumption and pollution in cities. The author observes, with reference to the twenty-seven countries of the European Union: “[...] notes that $25 \%$ of greenhouse gas emissions, and more than $30 \%$ of the total energy consumed in 2010, was due to the transportation sector. It is significant that over $90 \%$ of these results are from non-renewable sources. Furthermore, urban mobility accounts for $40 \%$ of transportation's $\mathrm{CO}_{2}$ emissions."

The concerns referred to herein regarding the scope of the concept of intelligent mobility are justified on the basis of concrete data, such as the fact that between 1990 and 2007, road transport in the European Union increased by 29\% and car ownership, in that period, increased by $34 \%$, and this transport model is responsible for $23 \%$ of the energy consumed in Europe, and about three quarters of which depends on transport roads, not forgetting that the bad can worsen, given the estimate of that energy consumption in this sector will increase by around $80 \%$ by 2030 (Ortolani, 2014).

Another hopeless scenario projection for the future, which requires this more extensive understanding of the concept of smart mobility, is the prediction that by 2050 the urban population will represent $68 \%$ of the world population, which will necessarily have repercussions on investments for building construction and transportation systems to meet the needs of the population. Consequently, urban mobility will be the main source of pollution, resulting from gas emissions from the urban transport system estimated at around 60\% of total greenhouse gas emissions (Lopes Toledo; Lèbre La Rovere, 2018).

The aforementioned process of expansion of cities creates polycentric structured cities, which, due to the various decentralized centers, encourage greater dependence on private cars due to increased distances and the lack of competitiveness in public transport in areas of low population density (Monzón de Cáceres \& Hoz Sánchez, 2009). That results in congestion and other consequences related to the time and cost of waiting for drivers. For example, in the city of Los Angeles, drivers spend about 102 hours a year in traffic jams, costing the city about US\$19.2 billion. In Moscow, drivers spend 91 hours in traffic jams (Cookson, 2018). The city of Recife was ranked 23rd in the world ranking of worst traffic in the world, because drivers spent 135 hours in traffic jams in the year 2020 (Tom Tom Traffic, 2020).

The premise for smart mobility is the use of technology in urban management and planning to improve knowledge of spatial conditions and services in order to change people's habits, avoid waste, benefit the environment and improve the efficient use of natural resources. After all, urban mobility impacts other axes of smart cities, such as sustainability, economy and lifestyle, which makes this a basic issue for residents and local governments (Aletà; Alonso \& Ruiz, 2017).

Moreover, according to the Sustainable Development Goals (SDGs) of the 2030 Agenda defined by the United Nations, the challenges of urban mobility can be addressed through planned actions that will help build more sustainable cities. Therefore, urban mobility is present in: SDG 3 (Good health and well-being), SDG 7 (Affordable and clean energy), SDG 9 (Industry, innovation and infrastructure), SDG 11 (Sustainable cities and communities), SDG 12 (Responsible Consumption and Productions) SDG 13 (Climate action) and SDG 17 (Partnerships for the goals) (Plataforma Agenda 2030, 2021).

Thus, Bucchiarone (2019) explains that modern cities try to flexibly integrate transport options to be used by residents 
and visitors like buses, trains, taxis, bikes and cars, which play an important role in the city's economy and quality of life for its residents. This is why it is said that mobility and transport planning play a fundamental role in economic and social development. That said, Rodríguez Bustamente (2015) notes that, in the area of mobility, planning must prevail over technology and actions must aim to organize modes of transport, including the on foot, in terms of importance and meaning.

The conception in question about intelligent mobility encourages the elaboration of actions to facilitate urban mobility. Among them, it is possible to mention the investment in electric buses and car sharing services (combustion and electric), bikes, electric scooters, use of intelligent traffic lights, development of vehicular networks (Vehicular Ah-Doc Networks - VANETs), and others. It is true that, when thinking about these proposals, one should not forget the need for parking lots, charging stations, construction of bike paths and the creation of protected routes for trips to and from school. It is verified that the examples mentioned here aim to promote urban development and environmental sustainability, as they offer new service strategies aimed to reduce $\mathrm{CO}_{2}$ emissions, and therefore, better quality of life for the population.

\section{Urban Mobility Overview: Promising Initiatives Around the World 6.1 Asia}

The world, or at least a good part of it, already breathes the "air" of the fourth industrial revolution. The statement is justified based on the fact that the defining characteristic of industry 4.0 is the "convergence of digital, physical and biological technologies to solve problems" (Hulse \& Chih, 2019, p. 01), a characteristic that is present in the concepts of smart city and smart mobility. Thus, the development of ICT tools with the purpose of solving problems arising from the impacts of urbanization is more frequently observed.

Singapore is one of the countries that stands out for pioneering the adoption of industry 4.0, in addition to, in recent years, topping the first place as a smart city in the rankings of the World Economic Forum (WEF, 2020), of the IMD Smart City Index (2020) and Smart City Government (2020). In fact, Singapore is a city-state, which has developed an organization, considered exemplary, not to depend on the natural and economic resources from another nation, as well as to be politically independent, which boosted the habit of innovation (HIROKI; CARDOSO, 2016).

The small Asia nation is also often awarded with the title of First Nation Considered Smart, or Smarter City (Cavada; Tight \& Rogers, 2019). It is worth noting that it is small in territorial extension, but with a population of 5.54 million, in June 2015, and is projected to grow in 2030, between 6.5 and 6.9 million, due to a constant flow of non-residents and migrants (NPTD, 2013). Given these factors, among others, Singapore has become responsible for long-term planning for urban mobility, with the aim of becoming a potential model country in the transformation of land transportation and the design of the smart city of the future.

To get an idea of the advances already made in Singapore since 2014 the Committee on Autonomous Road Transport for Singapore (CARTS) was created to study autonomous vehicle applications, regulations, and implementation. From the outset, four application areas were identified: (1) fixed and scheduled services for efficient mass transportation, (2) point-to-point or mobility-on-demand services, (3) freight, and (4) utility operations (Huiling \& Goh, 2017).

Another example of advances for this segment is the forecast to reduce the intensity of greenhouse gases by 36 percent compared to 2005 levels by 2030 (National Climate Change Secretariat, 2016). The promise was announced during the climate negotiations of the 21st Conference of the Parties (COP-21), in Paris in 2015 which will certainly impact the transport sector, which contributes substantially to the emissions of greenhouse gases in Singapore.

Furthermore, the real concern with urban mobility has led the Singapore government to adopt tools such as the vehicle quota system and the road charging system to control vehicle growth and manage road congestion. However, although these models have proven to be effective so far, it is believed that these strategies cannot continue to support future needs, which are 
reasons that led Singapore to actively adopt autonomous vehicles (Huiling \& Goh, 2017).

Regarding autonomous vehicles, it is necessary to clarify that Singapore's plan is to continue to value public transport for mass displacement, since the introduction of autonomous vehicles is not intended to make public transport obsolete, short or mid-term. In fact, the intention is that autonomous vehicles are used as complementary means of public transport, such as the use of autonomous buses, for first and last mile trips. It is also intended to use autonomous vehicles in mobility as a car-sharing and ride-sharing service, so they are not intended to directly replace human-driven cars. (Huiling \& Goh, 2017). Furthermore, considering that elderly residents will represent about a quarter of Singapore's population by 2030 (NPTD, 2013), autonomous vehicles can provide mobility for the elderly and people with disabilities.

It is worth noting that the Singapore Ministry of Transport estimates that the full adoption of autonomous vehicles will only take about 10 to 15 years (Singapore, 2017). Even so, it is already possible to observe that, the implementation of these personal mobility devices to complement public transport services, with autonomous feeder bus for first and last mile trips and autonomous vehicles for sharing along with data analysis, can reduce traffic congestion by driving vehicles around the city more efficiently (Zahraei; Kurniawan \& Cheah, 2020).

\subsection{Europe}

In the European continent there are also several programs and strategies aimed at the theme of urban mobility. Among them, it is opportune to mention the Horizon 2020 program under development by the European Union (EU), with a total planned investment of 6.3 billion euros. The program was launched in 2013, with the objective to provide financing to get four main objectives: (1) a resource efficient transport that respects the environment; (2) better mobility, less congestion, more safety and security; (3) global leadership for the European transport industry; and (4) conducting socio-economic and behavioural research and forward looking activities for policy making (EUROPEAN COMMISSION, 2021).

However, according to the rankings of the World Economic Forum (WEF, 2020), the IMD Smart City Index (2020) and the Top 50 Smart City Government (2020), there are divergences regarding the first positions with regard to European cities. That said, to continue the study of the main smart cities in the world, the Top 50 Smart City Government ranking was chosen, due to the methodological approach applied to define the classification, which considered the role of the top 50 municipal governments in promoting development of smart cities, based on ten key factors described: (1) vision; (2) leadership; (3) budget; (4) financial; (5) support programmes; (6) policies; (7) ecosystems; (8) people-centricity; (9) talent-readiness; (10) track record (Smart City Government, 2020).

According to the Top 50 Smart City Government ranking (2020), the cities of London in England and Barcelona in Spain, show the best rankings among cities in Europe, that is, in third and fourth place respectively. London is internationally known for the quality of public transport, especially due to the punctuality offered by the system. Transport for London (TfL) is the single body responsible for operating the entire public transport system in Greater London. London's extensive public transport system covers: Bus, Underground (tube), Overground, light metro in the Docklands region (Docklands Light Railway - DLR), Trams, Emirates Airline and River bus.

Kamargianni et al. (2015) explain that, with the introduction of the Oyster card in the TfL system the population started to use public transport more frequently. This is because the aforementioned smart card offers prepayment modalities, that is, payment for each trip at the point of travel, and as a ticket for mobility packages (travelcards), according to the options provided by TfL. The growth in the use of public transport in London represents a significant increase of 53\% in the use of Bus Patronage, almost two billion rides per year, and also an increase of almost 20\% underground (tube) rides and more than 100\% in DLR rides (Kamargianni et al, 2016).

The main contributor to poor air quality in London turns out to be caused by the road transport (Gleave, 2017). However, 
since 2003, London city has been betting on car sharing as a new transport strategy in the city, they are called Car Clubs, but they are also known as Car Sharing. The car sharing market, through car clubs, has become one of the largest in Europe (Akyelken; Banister \& Givoni 2018), both in terms of the number of car club members and the geographic coverage of car clubs in London (Kamargianni, et al., 2016).

A Carplus survey (Gleave, 2017) found that for every vehicle in the car club in London, 10.5 private cars are taken off the road. This reduction in the amount of acquisition and ownership of vehicles has a positive impact on $\mathrm{CO}_{2}$ reduction. According to this survey, the car club fleet emits an average of $29 \%$ less $\mathrm{CO}_{2}$ than the average of other vehicles and $99 \%$ of the car club's vehicles are already in compliance with the Ultra Low Emission Zone (Ultra- Low Emission Vehicles - ULEVs) proposed for London. ULEVs use low carbon technologies, which emit less than $75 \mathrm{~g} \mathrm{CO}_{2} / \mathrm{km}$ from the tailpipe. Reinforcing this change in behavior, shows that the number of ULEVs in the fleet increased from 251 in 2014/15 to 293 in 2015/16, of which 68 were electric vehicles with zero-emission exhaust pipe battery (Gleave, 2017).

Thus, considering reducing the need of travel and car use, has become one of the most effective policy options in London (Docherty \& Shaw, 2011), Carplus research demonstrates the already known benefits of implementing this policy, as shown by that over time, membership in the car club reflects that more members do not buy private cars. In 2016/17, 27\% of interviewed said they would have bought a car if they had not become members of the car club. As a positive consequence, the reduction of cars in traffic means less congestion, as well as a reduction in $\mathrm{CO}_{2}$ emissions. The ULEVs of the London Car Club fleet saved 1,190 tonnes of $\mathrm{CO}_{2}$ in 2016 (Gleave, 2017).

Regarding the Spanish cities, Aletà, Alonso and Ruiz (2017) point out that the cities with the best ranking in the six smart axes are Barcelona, Madrid and Valencia. And among the Smart Mobility and Environment initiatives the authors present the EU-funded project entitled Physical Activity Through Sustainable Transport Approaches (PASTA, 2021), as an example of a mobility initiative that promotes physical activity through sustainable mobility and connects transport and health in Barcelona as it encourages activities such as walking and cycling.

Another concrete example of smart mobility is line 9 of the metro in the city of Barcelona. It represents Barcelona's most recent and advanced initiative to achieve greater collective mobility. It will be 47.8 kilometers long, making it the longest underground metro in Europe. Trains will be automated, driverless, plus other smart mobility and control solutions to quickly get passengers to their destinations and provide direct links to long-distance train stations, airports and other transport options. The 52 stations planned will allow around 350.000 people a day (130 million passengers a year) to reach their destinations more quickly and easily (Urban Hub, 2021).

\subsection{North America}

After European cities, according to the ranking of the Top 50 Smart City Government (2020), the cities of New York in the United States of America (USA) and Montreal in Canada represent North America in the 6th and 7th placements respectively. New York is the most populous city in the USA, and like any city of its size, it faces traffic problems. To get an idea of the magnitude of the problem, 1.9 million people use the bus system daily, which is considered the slowest in the country, since the average speed of public transport buses is around 11 kilometers per hour (Shah; Kothari \& Doshi, 2019). Considering the speed of buses in New York City, cycling can be more advantageous in different ways.

The city of New York offers bike-sharing service, from 2013 through CitiBike project, touted as the largest bike-sharing service in North America according Chiariotti et al (2018), with approximately 800 stations and 13.000 bikes (Shah; Kothari \& Doshi, 2019). Surely, bikes have been used as a means of transportation to travel to work and school. Chiariotti et al (2018) argue, when analyzing a typical commuter station in July 2015, that during the week peak times are in the morning and evening, given that the season is probably used by students and workers, so there are more arrivals than departures in the morning, and 
more departures than arrivals at night.

The authors also report, among the positive data, that most bike trips take less than 10 minutes and are used to cover an average distance of $2 \mathrm{~km}$. They also demonstrate the proximity between bike sharing stations to the closest subway entrance. Grand Central Station, the station with the highest average demand, is one of the examples that fits the pattern of use of bikesharing as a complementary service to mass public transport. (Chiariotti, et al., 2018). In this sense, it is observed that bikesharing can supply this need for a last-mile transport option.

However, as a standard, bike-sharing stations tend to serve more affluent and central neighborhoods, so much that in New York City the stations are concentrated in the neighborhoods of Manhattan and Brooklyn, while providing limited coverage in economically disadvantaged neighborhoods. In any case, it is opportune to clarify that bike-sharing impacts can be seen by reducing the number of passengers in public transport and the use of private cars, as well as on the pre-existing infrastructure and the socioeconomic scenario (Pase, et al., 2020).

The city of Montreal also made investments in the cycling network, so much that Houde, Apparicio and Séguin (2018) point out that in 25 years (1991 to 2016) there was an increase in length more than the double, precisely, from $270 \mathrm{~km}$ to 732 $\mathrm{km}$. According to the authors, in the early 2000s, Montreal was recognized as the Canadian city with the highest level of use of bikes to commute to work, despite the harshest winter compared to other Canadian metropolitan areas (Houde; Apparicio \& Séguin, 2018).

Montreal has a population of 1.7 million, according to 2016 census data, it is the largest city in the province of Quebec, and like most large cities faces problems related to public transportation (Bista; Hollander \& Situ, 2021). In fact, one of the issues to be overcome concerns a very common situation in large cities, and already mentioned here, which is the last-mile, that can be updated to the "first/last mile". It refers to the displacement distance and the lack of connectivity between the location and the station, or between one and another public transport station, or even from the station to the destination.

Bista, Hollander and Situ (2021) state that people are willing to travel an average of $1 / 4$ (a quarter) of a mile to the public transport stop, which corresponds to 402.34 meters. In this sense, considering that public transport is the least attractive means of choice when users cannot easily connect to their destination (Zellner, et al., 2016), it is therefore essential to think about reliable transport networks to connect people and places, and therefore solve the first/last mile problem.

In the literature there are a variety of proposals to resolve this issue, among them the most recurrent are bike-sharing, ride-sharing, car-pooling and high occupancy vehicle (HOV) lanes. In the official documents of the city of Montreal, in the Master Plan of 2004, the aforementioned problem related to the last-mile is identified as well as the concern to solve them. In the document, the terms referring to intermodal connections and active transport are present along with the concern about the need to introduce various modes of transport as a solution to the problem of the first/last mile (Bista; Hollander \& Situ, 2021).

Bike-sharing and car sharing are the solutions already implemented in Montreal. As for bike-sharing, the authors mention in the research that in Montreal an additional $300 \mathrm{~km}$ of cycle paths are being added to better connect the active mode of transport. However, the aforementioned cycle paths will be concentrated in the more developed neighborhoods, which are the central areas that allow the incorporation of mixed-use means of connections with public transport (Bista; Hollander \& Situ, 2021).

\subsection{Brazil}

Cities in Central and South America are hardly found in the world rankings among the top 50 smart cities. Even so, that does not mean they do not exist. As an example, the national ranking Connected Smart Cities, ranks the cities in Brazil that have developed the most in relation to the 11 (eleven) thematic axes analyzed: mobility, urbanism, environment, technology and innovation, entrepreneurship, education, health, safety, energy, governance and economy (Ranking CSC, 2020). 
Adopting the same criterion of selecting the two best positioned cities, according to the mobility and accessibility axis, the cities of São Paulo (SP) and Brasília (DF) appear in 1st and 2nd places in the Connected Smart Cities ranking (Ranking CSC, 2020).

In Brazil, Law n. 12.587/12 implemented the guidelines of the National Policy on Urban Mobility - PNMU, as well as establishing the obligation for municipalities with more than twenty thousand inhabitants to prepare the Urban Mobility Plan PlanMob. Therefore, in order to obtain federal funds for mobility projects, the administration in municipalities with more than twenty thousand inhabitants must prepare their urban mobility plans in order to create sustainable urban mobility (Hashisaka Junior; Russo \& Patah, 2019).

According to the authors, the city of São Paulo justifies its first place in the Connected Smart Cities ranking, not necessarily because it has implemented a recognizably effective urban mobility system, but because it manages the portfolio of projects in public management, with the selection of road infrastructure projects and transport services, such as the expansion of subway lines and plans for the construction of new branches, a factor that would have contributed to the result obtained (Hashisaka Junior; Russo \& Patah, 2019).

However, some projects to improve urban mobility have already come to fruition, such as the implementation of more than $400 \mathrm{~km}$ of exclusive lanes to the right of the roads to improve the speed of bus circulation in the city of São Paulo. Another strategy was to release these exclusive lanes for taxi drivers, at any time and day of the week, with the condition that they are transporting passengers. The implementation of exclusive bus lanes yielded a speed improvement of 50\% in the morning peak and $40 \%$ in the afternoon peak. In terms of time saved for the passenger, this is equivalent to 40 minutes (Tatto, 2015).

The city of Brasília, on the other hand, although it appears in the aforementioned ranking in 8th place overall, is in 2nd position considering the mobility and accessibility axis. Presented among the 30 goals of President Juscelino Kubitschek's Program, at the end of 1955 , whose motto was "50 years of progress in 5 years", Brasília was built and became the federal capital of Brazil. The capital of hope, as it was called, was based on a project considered quite innovative, arising from the fusion of urban design by Lúcio Costa and architectural design by Oscar Niemeyer, which favored the circulation of cars (Coelho, 2008).

Thus, the accelerated population growth soon began to face the limitations of the city's structural design, including urban mobility. The city's Pilot Plan was performance as planned, with great distances between the autonomous sectors, where the car became the main means of transport to enable people to move around. As a consequence of this, it appears that while the national average is 1 car for every 4 inhabitants, in Brasília the number is 1 car for every 2.56 inhabitants (Dantas, 2015).

However, the Federal District Government intends to reverse this reality and already announces that the Federal District has the largest road network in Brazil, which would justify the 2nd position in the ranking. Apparently, there was a 20\% increase in the extension corresponding to the set of exclusive lanes for bikes, skateboards and other non-motorized means of transportation, increasing from 466.6 kilometers at the end of 2018 to 553.95 kilometers in July 2020. The Active Mobility Plan aims precisely to make the bike the main complement to public transport to replace cars, as well as to integrate sections where interruptions in bike paths and bike lanes are still observed (Agência Brasília, 2020).

Cities such as Foz do Iguaçu (PR) and Petrolina (PE), which are located in Brazil inland, are far from the top positions in the national ranking. It is also possible to identify smart city initiatives, which deserve to be highlighted for the vanguard of the proposals, is the use of the Sandbox by the municipal governments of the cities of Foz de Iguaçu and Petrolina, a platform for testing and experimentation, which provides an unregulated environment for research and validation of technologies (ABDI, 2021).

In the city of Foz do Iguaçu, Decree n. 28.244, of June 23, 2020 was published with the objective of regulating, within the municipality, the institution of experimental environments for scientific, technological and entrepreneurial innovation, under the format of Regulatory and Technological Test Banks - "Sandbox Program - Foz do Iguaçu" (Foz do Iguaçu, 2020). 
This program aims to install technologies in Village A, making it the first smart public neighborhood in Brazil. Although quite recent, there are already four companies testing their technologies in the environment of the Smart Village A (Parque Tecnológico Itaipu, 2021). The program aims to install intelligent lighting fixtures in Smart Village A, complete with integrated facial recognition cameras, as well as smart bus stops and smart traffic lights, the implementation of an Operations Control Center (CCO) and the monitoring of license plates (ABDI, 2020).

The city of Petrolina, also by Decree n. 61, on August 13, 2020, became the first city in the Northeast region to implement the Living Laboratory through the Sandbox Program (Petrolina, 2020). The objective in Petrolina is to conduct tests and develop new technologies to achieve the municipality's needs. In the project, the installation of smart traffic lights, smart public lighting, high definition cameras and artificial intelligence software for facial and license plate recognition is foreseen. (Melazo, 2020).

\section{Final Considerations}

Over centuries, cities have suffered profound impacts promoted by industrial revolutions, which culminated in substantial interference in numerous aspects of urban life, such as property architecture, urban planning, public policy development, city infrastructure, behavior of its inhabitants, among others. However, what has not changed in cities is their socio-cultural relevance.

Certainly, when the first human groupings decided to abandon nomadic life and settle territory, cultivate the land and build permanent homes for their families, they did not imagine the difference that such decision-making would make in the future of humanity, that is, that those simple villages could result in the complex contemporary megalopolises. The most curious thing is that even now, immersed in a society with access to so much information, under the effects of digital transformations which allow human beings to imagine the next steps of technological innovations, whether close or remote it is still unclear or at least uncertain the fate of humanity.

Cities, particularly the largest and most populous, started presenting problems capable of significantly affecting people's health and well-being. The rapid urbanization of the main urban centers as a result of industrialization did not allow for an immediate diagnosis of the long-term damage affected by the swelling of cities. It is no longer about assumptions or evidence to be questioned. The inhabitants of the Earth planet already daily live with the problems arising from the overpopulation of cities and the lack of awareness and concern with urban planning and sustainable development.

Facing this situation which reveals real samples of an announced global catastrophe, concepts of smart cities emerge based on ICTs, in order to implement positive initiatives to change the current reality of cities and their residents. And as previously mentioned, although there are several concepts of smart city, it is possible in an objective way, to concentrate on three elements considered essential and present, sometimes using other terms, in all concepts of smart city are: instrumented, interconnected and intelligent.

The installation of technological instruments to collect data in cities, which allow the interconnectedness of information to enable the creation of intelligent service delivery models, has the potential to measure the quality of the thematic axes mobility, urbanism, environment, technology and innovation, entrepreneurship, education, health, security, energy, governance and economics, and thus to think and offer innovative products and services, as well as an opportunity to improve the well-being of citizens and the industrial development of the city.

In fact, this is what is already happening in different parts of the world with regard to the axis corresponding to mobility. New proposals for mobility systems created based on instrumentality, interconnectivity and intelligence are gaining ground and gradually occupying urban spaces. These are projects that propose the use of a sharing economy, improvement and expansion of public transport, sustainable mobility, products with low emission of polluting gases, technologies to reduce the time spent on 
traffic.

However, it is a very slow and difficult process to be implemented, because the initiatives mentioned above, although beneficial for cities and their inhabitants, require a change in the culture and society education, which in itself is already complicated, but it is not enough, since in addition, it is necessary to fight against the forces of capitalism, within a capitalist system unconcerned about investing in sustainable development initiatives, because it considers them to be of low profitability.

Finally, considering the proposed objective for this article, a data collection of the most recent and important smart mobility systems already implemented in the main cities of the world was carried out through a literature review, which allowed/allow not only the dissemination of these experiences, but also assess which of them effectively provided/provide the promised improvement in the quality of life of the population.

\section{References}

Abdala, L. N., et al. (2014). Como as cidades inteligentes contribuem para o desenvolvimento de cidades sustentáveis - Uma revisão sistemática de literatura. Int. J. Knowl. Eng. Manag, 3, 98-120.

ABDI, Agência Brasileira de Desenvolvimento Industrial. (2020). Bairro Inteligente em Foz do Iguaçu. https://www.abdi.com.br/postagem/bairro-inteligenteem-foz-do-iguacu

ABDI, Agência Brasileira de Desenvolvimento Industrial. (2020). Living Lab. https://www.abdi.com.br/projetos/living-lab

Abiko, A. \& Moraes, O. B. (2009). Desenvolvimento urbano sustentável. Texto Técnico. Escola Politécnica da USP. Departamento de Engenharia de Construção Civil.

Abreu, M. A. (1998). Sobre a memória das cidades. Revista Território, 4, 5-26 http://mauricioabreu.com.br/files/artigos/Sobre\%20a\%2 0memoria\%20das\%20 cidades.pdf

Agência Brasília. (2020). Trechos de ciclovias no DF aumentam 20\% desde 2019. https://www.agenciabrasilia.df.gov.br/2020/08/20/trechos-de-ciclovias-nodf-aumentam-20-desde-2019/

Akyelken, N., Banister, D., \& Givoni, M. (2018). A Sustentabilidade da Mobilidade Compartilhada em Londres: O Dilema para a Governança. Sustentabilidade, 10,420 .

Albino, V., Berardi, U. \& Dangelico, R. M. (2015). Smart Cities: Definitions, Dimensions, Performance, and Initiatives. $37-41$.

Aletà, N. B., Alonso, C. M. \& Ruiz, R. M. A. (2017). Smart Mobility and Smart Environment in the Spanish cities. Transportation Research Procedia 24C, $163-170$.

Ayub, U. (2016). Mobilidade: uma questão para o planejamento urbano. Dissertação (Mestre em Arquitetura e Urbanismo) - Universidade São Judas Tadeu. São Paulo, 123 p.

Barbosa, A. G. (2016). Planejamento urbano empresarialista em complexos imobiliários, residenciais e de serviços: a Reserva do Paiva em análise. Cad. Metrop. $18,785-802$.

Bista, S., Hollander, J. B. \& Situ, M. (2021). A content analysis of transportation planning documents in Toronto and Montreal. Case Studies on Transport Policy, 9, 1-11.

Bresser-Pereira, L. C. (2014). Desenvolvimento, progresso e crescimento econômico. Lua Nova, 93, 33-60.

Brundtland, G. H. (1987). Our Common Future: Report of the World Commission on Environment and Development. United Nations Commission, 4, 300.

Bucchiarone, A. (2019). Collective Adaptation through Multi-Agents Ensembles: The Case of Smart Urban Mobility. ACM Trans. Auton. Adapt. Syst. 14, 1-28.

Caragliu, A., Del Bo, C. \& Nijkamp, P. (2009). Smart cities in Europe. 3rd Central European Conference in Regional Science - CERS.

Carvalho, S. N. (2001). Elementos conceituais para a discussão de modalidades de políticas de planejamento urbano. In: Encontro Nacional da Anpur (9/2001, Rio de Janeiro). Anais: ética, planejamento e construção democrática do espaço. Anpur.

Cavada, M., Tight, M. R. \& Rogers, C. D. F. (2019). A smart city case study of Singapore - Is Singapore truly smart? Smart City Emergence, Cases From Around the World, 295-314.

Centre of Regional Science. (2007). Smart cities: ranking of European medium-sized cities. http://www.smart-cities.eu/download/smart_cities_final_report.pdf Chiariotti, F., Pielli, C., Cenedese, A., Zanella, A. \& Zorzi, M. (2018). Bike sharing as a key smart city service: State of the art and future developments. In. 2018 7th International Conference on Modern Circuits and Systems Technologies (MOCAST), 1-6.

Chourabi, H., Nam, T., Walker, S., Gil-Garcia, J. R., Mellouli, S., Nahon, K., Pardo, T. A \& Scholl, H. J. (2012) Understanding Smart Cities: An integrative framework. In IEEE Computer Society, Proceedings of the 45th Hawaii International Conference, 2289-2297. 
Coelho, C. M. (2008). Utopias urbanas: o caso de Brasília e Vila Planalto. Cronos, Natal-RN, 9, 65-75.

Cookson, G. (2018). “Inrix global traffic scorecard,” INRIX Research.

Cury, M. J. F. \& Marques, J. A. L. F. (2017). A cidade inteligente: uma reterritorialização. Redes - Santa Cruz do Sul: Universidade de Santa Cruz do Sul, 22, $102-117$.

Dantas, A. B. A. (2015). Suporte móvel para estacionamento de bicicletas para a cidade de Brasília. 2015. 40 f., il. Monografia (Bacharelado em Desenho Industrial) - Universidade de Brasília, Brasília.

Delfim Netto, A. (2008). O papel do Estado é igual. Entrevistado por Jorge Luiz de Souza. In. IPEA. Desafios do desenvolvimento. IPEA, 39. https://www.ipea.gov.br/desafios/index.php?option=com_content\&view=article\&id=1349:entrevistas-materias\&Itemid=41

Dobbs, R., Smit, S., Remes, J., Manyika, J., Roxburgh, C., \& Restrepo, A. (2011). Urban World: Mapping the Economic Power of Cities. Journal of Monetary Economics. 36 (March): 49

Docherty, I., \& Shaw, J. (2011). The Transformation of Transport Policy in Great Britain? 'New Realism' and New Labour's Decade of Displacement Activity. Environment and Planning A: Economy and Space. 43(1), p. 224-251.

Elias, S \& Krogstie, J. (2017). Smart sustainable cities of the future: An extensive interdisciplinary literature review. Sustainable Cities and Society, 31, 183212.

European Commission. (2020). Horizonte 2020. https://ec.europa.eu/programmes/horizon2020/en/h2020-section/smart-green-and-integrated-transport\%20

Flores, L. (2010). Progress Towards Sustainability in Urban Planning: San Francisco and Montreal. Focus: Journal of the City and Regional Planning Department, 7, 69-76.

Flores, L. E. B. \& Teixeira, C. S. (2017). Cidades sustentáveis e cidades inteligentes: uma análise dos rankings arcadis e european smart cities. REAVI, 6, 6876.

Foz do Iguaçu. (2020). Decreto n. 28.244, de 23 de junho de 2020. https://leismunicipais.com.br/a/pr/f/foz-do-iguacu/decreto/2020/2825/28244/decreto-n28244-2020-regulamenta-no-ambito-do-municipio-de-foz-do-iguacu-a-instituicao-de-ambientes-experimentais-de-inovacao-cientifica-tecnologica-eempreendedora-sob-o-formato-de-bancos-de-testes-regulatorios-e-tecnologicos-programa-sandbox-foz-do-iguacu

Gleave, S. D. (2017). Carplus annual survey of car clubs 2016/17 London. https://como.org.uk/wp-content/uploads/2018/06/Carplus-Annual-Survey-of-CarClubs-2016-17-London.pdf

Harrison, C., Eckman, B., Hamilton, R., Hartswick, P., Kalagnanam, J., Paraszczak, J. \& Williams, P. (2010). 'Foundations for smarter cities', IBM Journal of Research and Development 54(4), p. 1-16.

Hashisaka Junior, C., Russo, R. F. S. M. \& Patah, L. A. (2019). A influência da seleção de projetos para a criação de uma mobilidade urbana inteligente: o caso da cidade de São Paulo. In: XLIII Encontro da ANPAD - EnANPAD 2019, p. 1-17.

Hiroki, S. \& Cardoso, T. (2016). Relato de experiência: a utilização do pensamento complexo para a organização de uma cidade inteligente e planetária, o caso da cidade de Cingapura. In: Anais da Conferência Internacional: Saberes para uma Cidadania Planetária. Conferência Internacional, 24 a 27 de maio. http://uece.br/eventos/spcp/anais/trabalhos_completos/247-38720-29032016-212034.pdf

Holzer, M. \& Kim, S. (2006). Digital Governance in Municipalities Worldwide: A Longitudinal Assessment of Municipal Websites Throughout the World. EGovernance Institute, National Center for Public Productivity.

Houde, M., Apparicio, P. \& Séguin, A. (2018). A ride for whom: Has cycling network expansion reduced inequities in accessibility in Montreal, Canada. Journal of Transport Geography, 68, 9-21.

Huiling, E. \& Goh, B. (2017). AI, Robotics and Mobility as a Service: the Case of Singapore. OpenEdition Journals, 26-29. https://journals.openedition.org/ factsreports/4411

Hulse, E. O. \& Chih, W. Y. (2019). Internet das Coisas e suas Aplicações na Mobilidade Urbana. WPLEX Software Ltda, 2019. https://www.wplex.com.br /artigos/2019-udesc-Internet\%20das\%20coisas\%20na\%20mobilidade\%20urbana.pdf

IBGE. Instituto Brasileiro de Geografia e Estatística. (2010). Sinopse do censo demográfico. https://censo2010.ibge.gov.br/sinopse/index.php?dados=8

ICLEI, International Council For Local Environmental Initiatives. (19959. European Local Agenda 21 Planning Guide. How to engage in long - term environmental action planning towards sustainability. Friburgo: ICLEI.

IEDI, Instituto de Estudos para o Desenvolvimento Industrial (2018). https://www.iedi.org.br/

IMD, Institute for Management Development. Smart City Index. (2020). https://www.imd.org/smart-city-observatory/smart-city-index/

Kamargianni, M., Li, W., Matyas, M. \& Schäfer, A. (2016). A critical review of new mobility services for urban transport. Transportation Research Procedia, 14, p. 3294-3303.

Kamargianni, M., Li, W., Matyas, M. \& Schäfer, A. (2015). Feasibility Study for "Mobility as a Service” concept in London. Technical Report, June.

Kennedy, C., Cuddihy, J. \& Engel-Yan, J. (2007). The Changing Metabolism of Cities. Journal of Industrial Ecology, 11, 43-59. 
Kobayashi, A. R. K., Kniess, C. T., Serra, F. A. R., Ferraz, R. R. N. \& Ruiz, M. S. (2017). Smart Sustainable cities: bibliometric study and patent information. International Journal of Innovation, 1(5), 77-96.

Komninos, N. (2008). Cidades Inteligentes - Sistemas de Inovação e Tecnologias da Informação ao serviço do Desenvolvimento das Cidades. 2008. http://www.urenio.org/wp-content/ uploads/2008/11/cidades-inteligentes.pdf

Lopes Toledo, A. \& Lèbre La Rovere, E. (2018). Urban Mobility and Greenhouse Gas Emissions: Status, Public Policies, and Scenarios in a Developing Economy City, Natal, Brazil. Sustainability, 10, 3995-4018.

Lopez-Carreiro, I. \& Monzon, A. (2018). Evaluating sustainability and innovation of mobility patterns in Spanish cities. Analysis by size and urban typology. Sustainable Cities and Society, 38, 684-696.

Manville, C., Millard, J., Liebe, A. \& Massink, R. (2014). Mapping Smart Cities in the EU. Industry, Research and Energy, European Parliament.

Melazo, F. (2020). Agência Brasileira de Desenvolvimento Industrial - ABDI. Petrolina: Primeira cidade do Nordeste a implantar laboratório vivo. In: Agência Brasileira de Desenvolvimento Industrial - ABDI. https://www.abdi.com.br/postagem/petrolina-primeira-cidade-do-nordeste-a-implantar-laboratorio-vivo

Monzón De Cáceres, A. \& Hoz Sánchez, D. (2009). Efectos sobre la movilidad dinámica territorial de Madrid. Revista del Departamento de Ubarnística y Ordenación del Territorio.

Musakwa, W. \& Niekerk, A. (2015). Earth Observation for Sustainable Urban Planning in Developing Countries: Needs, Trendsand Future Directions. Journal of Planning Literature, 30. 149-160.

National Climate Change Secretariat. (2016). National Climate Change Secretariat's Addendum to the President's Address in 2016 by Deputy Prime Minister Teo Chee Hean, Chairman of the inter-ministerial committee on climate change, Singapore.

Neirotti, P., De Marco, A., Cagliano, A. C., Mangano, G. \& Scorrano, F. (2014). "Current Trends in Smart City Initiatives: Some Stylised Facts.” Cities, 38, $25-36$.

NPTD, National Population and Talent Division. (2013). A sustainable population for a dynamic Singapore. http://population.sg/whitepaper/\#.VeZ5J_aqpBc

Ortolani, C. (2014). The cycling as a driver of a renewed design and use of public space within the neighborhoods. CSE-City Safety Energy (1), 51.

Pan, G., Qi, G., Zhang, W., Li, S., Wu, Z. \& Yang, L. (2013). 'Trace analysis and mining for smart cities: issues, methods, and applications', IEEE Communications Magazine 51, (6), 120-126.

Parque Tecnológico Itaipu. (2021). Vila a inteligente: Programa é apresentado para Iguassu Valley. https://www.pti.org.br/pt-br/content/vila-inteligenteprograma-é-apresentado-para-iguassu-valley\% $2 \% \mathrm{~A} 0$

Pase, F., Chiariotti, F., Zanella, A. \& Zorzi, M. (2020). Bike Sharing and Urban Mobility in a Post-Pandemic World. IEEE Access, 8, 187291-187306.

Paseto, L., Martins Martinez, M. R. \& Przeybilovicz, E. (2020). Cidades inteligentes e indústria 4.0: a influência das tecnologias da informação e comunicação. Revista Científica e-Locução, 1, 396-417.

PASTA, Physical Activity Through Sustainable Transport Approaches. (2021). https://pastaproject.eu/home/

Pellicer, S., Santa, G., Bleda, A. L., Maestre, R., Jara, A. J. \& Skarmeta, A. G. (2013). ‘A global perspective of smart cities: A survey’, Proceedings - 7th International Confe- rence on Innovative Mobile and Internet Services in Ubiquitous Computing, IMIS, 439-444.

Pesavento, S. J. (2007). Cidades visíveis, cidades sensíveis, cidades imaginárias. Revista Brasileira de História, 27, 11-23. https://www.scielo.br/pdf/r bh/v27n53/a02v5327.pdf

Petrolina. (2020). Decreto n. 61, de 13 de agosto de 2020. Diário Oficial da Prefeitura Municipal de Petrolina, edição n. 2.465, ano 10, 13 de agosto de 2020. https://petrolina.pe.gov.br/diario-oficial/

Pinna, F., Masala, F. \& Garau, C. (2017). Urban Policies and Mobility Trends in Italian Smart Cities. Sustainability, 9, 494, 1-21.

Plataforma Agenda 2030. (2021). http://www.agenda2030.com.br

Ranking CSC. (2020). Ranking Connected Smart Cities 2020. https://ranking.connectedsmartcities.com.br/resultados.php

Rodríguez Bustamante, P. (2015). Smart Mobility: Movilidad Inteligente En España. In. I Congreso Ciudades Inteligentes: Libro de Comunicaciones, p. 17075 .

Rother, E. T. (2007). Revisão sistemática X revisão narrativa. Acta paul. Enferm, 20 (2).

Sendler, U. (2013). Industrie 4.0: Beherrschung der industriellen Komplexität mit SysLM (Systems Lifecycle Management). Springer-Vieweg, Berlin.

Santos, A. M. S. P. (2006). Planejamento urbano: para quê e para quem? Revista de Direito da Cidade, 01, 51-94.

Shah, J., Kothari, J. \& Doshi, N. (2019). A Survey of Smart City infrastructure via Case study on New York. Procedia Computer Science, 160, $702-705$.

Silva, D. B. (2004). O planejamento urbano e a administração popular de Porto Alegre: discursos e práticas. Dissertação (Mestrado em Planejamento Urbano e Regional) - Faculdade de Arquitetura, Universidade Federal do Rio Grande do Sul. 189 p. 
Research, Society and Development, v. 10, n. 9, e18210917830, 2021

(CC BY 4.0) | ISSN 2525-3409 | DOI: http://dx.doi.org/10.33448/rsd-v10i9.17830

Singapore. (2017). Info-communications Media Development Authority. https://www.imda.gov.sg/infocomm-and-media-news/whats-trending/2017/2/driverles s-carspicking-up-speed-in-singapore

Smart City Government. (2021). Top 50 - smart city government. https://www.smartcitygovt.com

Souza, M. L. (2002). Mudar a cidade: introdução crítica ao planejamento urbano e à gestão urbanos. Bertrand Brasil.

Staricco, L. (2013). Smart mobility: Opportunità e condizioni. TeMA J. Land Use Mobil. Environ, 6, 341-354.

Summit Mobilidade Urbana. (2021). Quais são as cidades com os piores trânsitos do mundo. https://summitmobilidade.estadao.com.br/ir-e-vir-no-mundo/q uais- sao-as- cidades-com-o-pior-transito-do-mundo/

Tatto, J. A. (2015). Mobilidade urbana em São Paulo: aplicação de soluções imediatas e eficazes. Dissertação (Mestre em Ciências) - Escola Politécnica da Universidade de São Paulo. 163 p.

Tom Tom Traffic. (2021). Recife traffic. https://www.tomtom.com/en_gb/traffic-index/recife-traffic\#statistics

United Nations. (2018). 68\% of the world population projected to live in urban areas by 2050. https://www.un.org/development/desa/en/news/population/ 2018revision-of-world-urbanization-prospects.html

Urban Hub. (2021). Mobilidade inteligente para uma cidade inteligente: a Linha 9 liga Barcelona ao seu futuro. Smart Mobility. https://www.urban-hub.com/pt$\mathrm{br} /$ smart_mobility/mobilidade-inteligente-no-centro-da-cidade-inteligente-barcelona/

VEIGA, J. E. (2005). Desenvolvimento sustentável: o desafio do século XXI. Garamond.

WEF. Wold Economic Forum. (2020). https://www.weforum.org/

Zahraei, S. M., Kurniawan, J. H. \& Cheah, L. (2020). A foresight study on urban mobility: Singapore in 2040. FORESIGHT, Emerald Publishing Limited, 22 $37-52$.

Zellner, M., Massey, D., Shiftan, Y., Levine, J. \& Arquero, M. J. (2016). Overcoming the last-mile problem with transportation and land-use improve- ments: an agent-based approach. Int. J. Transp. 4 (1), 1-26. 